\title{
Remedial Online Teaching on a Summer Course | 19
}

\begin{tabular}{l}
\multicolumn{1}{c|}{$\begin{array}{l}\text { Draft paper: } \\
\text { Full paper published at: }\end{array}$} \\
$\underline{\text { http://www.ingentaconnect.com/content/ip/ihe/2006/00000020/00000005/ar }}$ \\
$\qquad \begin{array}{l}\frac{\mathrm{t} 00007}{-} \\
\text { Please cite as: }\end{array}$ \\
Rienties, B., Tempelaar, D. T., Waterval, D., Rehm, M., \& Gijselaers, W. H. (2006). \\
Remedial online teaching on a summer course. Industry and Higher Education, 20(5), \\
327-336.
\end{tabular}




\section{Chapter 2}

\section{REMEDIAL ONLINE TEACHING ON A SUMMER COURSE*}

\footnotetext{
This chapter is based on the experiences with remedial online learning from a national collaboration initiative of University of Amsterdam, Erasmus Rotterdam University and Maastricht University (http://www.web-spijkeren.nl). The central question is how prior knowledge tests and online remedial summer courses can contribute to mitigating the problems of heterogeneous enrolment of students.

Although the insights gathered in for this chapter come from pilots for first year bachelor programmes, the insights on how to successfully implement an online summer course programme can also be applied to other organisations.
}

\section{INTRODUCTION}

Acceptance to a bachelor or master programme has traditionally been based on a required (combination of) degree(s), experience and/or skills. However, due to increasing internationalisation of students (Ministerie van OCW , 2005), changes in secondary school programmes in the Netherlands (De Vries \& Van der Velden, 2005; Tweede Fase Adviespunt, 2005), the introduction of the bachelor-master structure and the new accreditation procedures by the Treaty of Bologna (Dittrich \& Frederiks, 2005; Onderwijsraad, 2005), higher education institutions face several tough

* Based upon:

Rienties, B., Tempelaar, D. T., Waterval, D., Rehm, M., \& Gijselaers, W. H. (2006). Remedial online teaching on a summer course. Industry and Higher Education, 20(5), 327-336. 
challenges in selecting the "correct" student. According to Ministerie van OCW (2005), the average percentage of foreign students in higher education in the Netherlands is $4 \%$ and most institutes strive for an increasing internationalisation in the years to come.

In the Netherlands, the two universities with the highest percentage of foreign students are University Wageningen (19\%) and Maastricht University (24\%). The experiences at the university with the highest amount of foreign students in both absolute as relative numbers show that prior knowledge levels of mathematics and economics of foreign students are more diverse and often lower than for students with a Dutch secondary education degree (Rienties, Dijkstra, Rehm, Tempelaar, \& Blok, 2005). Although foreign students formally should be accepted because of the Treaty of Bologna, for some (international) students, the lack of prior knowledge is too large and remedial teaching before entering a programme is desirable. In addition, most students are unable to judge whether they possess sufficient prior knowledge and/or experience to start a bachelor or master programme (Prins, 1997).

In the past, several remedial teaching programmes have been developed (e.g. Colloquium Doctum, J ames Boswell Institute). However, their success in terms of students completing the programme is highly dependent on the motivation of students, the involvement of teachers and the learning environments (Van Leijen, 2005). As higher education institutions now have to compete on a European or even global market, offering (only) regional/national remedial courses in a fixed (geographical) location with traditional teaching methods seems to neglect the effects of a changing world (of education). In order to increase the success rates of higher education, an online remedial programme could offer a solution to the problems of (lacks of) prior knowledge.

Therefore, in this chapter a general framework for an efficient and effective online summer course will be developed. Subsequently, the online remedial teaching model will be tested in practice by analysing two online remedial teaching courses at Maastricht University, which is part of the experiences of the project Web-spijkeren'. Finally, the evaluation results of the summer courses will be used to answer the following three questions: How can students assess their current level of mastery before joining a (bachelor) programme? In addition, if the level of mastery of individual students appears to be low, how can "online summer courses" help to tackle these potential deficiencies? And finally, how can online summer courses be designed to increase completion rates of students joining an online summer course? 


\section{ONLINE REMEDIAL TEACHING MODEL}

Van Leijen (2005) conducted research in various remedial teaching programs in the Netherlands. A programme offered during the summer period induces an incentive problem as most graduated high school students have a strong preference to do other things than studying. Hence, the challenge arises to construct a programme that achieves a balance between study time and time for summer activities in such a way that it provides sufficient motivation to keep students engaged in the course. An online summer course might be able to strike this balance, as it in theory should be possible to teach and learn regardless of time and place. On basis of various research on the use of ICT in education and distance education (Bryant, Khale, \& Schafer, 2005; Keegan, 2002; Roblyer \& Wiencke, 2003; Schellens \& Valcke, 2005; Vrasidas \& Mclsaac, 1999) and research on remedial teaching (Van Leijen, 2005), the following five aspects should be taken into consideration when an institute aims to design and implement an online remedial summer course:

1. Access and availability $24 / 7$ online

2. Adaptiveness

3. Interactivity

4. Responsiveness of feedback

5. Flexible learning method and assessment

22 Access and availability 24/7 online

According to Bryant et al. (2005), there are many definitions about online and/or distance education. Distance education encompasses two important elements, namely distance teaching and distance learning. Distance teaching regards mainly the way in which instruction is provided, whereas distance learning concerns optimising student learning behaviour (Keegan, 2002). Various definitions are used for online education. Although in most of the definitions terms like "web-enabled" and "online" point at the way instruction is provided, it does not automatically lead to distance education (Bryant et al., 2005). However, in this article the term online (education) is used instead of distance education as it allows bridging the limitations of time and geographical distance. In this way, students can work and study whenever they want, or so-called ubiquitous learning. Note that the term online mainly refers to technical educational issues. In order to learn independent of time and place, also organisational and didactical aspects have to be aligned. 


\section{Adaptiveness}

As each student is unique, the programme should ideally allow for an individualised learning path based on prior knowledge, learning style and preferences of the student (Abdullah, 2003; Doignon \& Falmagne, 1999). This means that the module should be flexible in meeting the needs of each individual participant.

\section{Interactivity}

Generally, in a face-to-face setting it is assumed that interaction is one of the key issues in the learning process (Vygotsky, 1978). According to Vrasidas and Mclsaac (1999), interaction is also a central component of online distance learning. "A fundamental component of distance education is the communication medium" (Bryant et al., 2005, p. 257). Being solely available online, the course and learning environment should stimulate interpersonal contact in order to motivate participants to remain engaged (Ronteltap \& Eurelings, 2002). However, in comparison to face-to-face education, it is harder to transfer communication elements like body language or intonation in a virtual education. Therefore, online courses have to make more intensive use of the available interaction methods (R oblyer \& Wiencke, 2003). Interaction is not just a technical mechanism; it is also a social and psychological way to generate relations. By forming small groups, students will experience peer-pressure, which forces them to interact more intensively. At the same time, group processes and learning processes remain clear and manageable for tutors (Schellens \& Valcke, 2005). In a model of Problem-based Learning setting (Moust, Bouhuijs, \& Schmidt, 2002), it is assumed that tutors together with students are responsible for stimulating interaction as well as stimulating the learning process.

\section{Responsiveness of Feedback}

Vrasidas \& Zembylas (2003) argue that feedback is a crucial factor in the interaction of a course. Besides the fact that it is pedagogically better to provide rapid feedback on performance, it is also important because the period before the summer course starts is short and often fully planned with other activities.

\section{Flexible learning method and assessment}

Given the fact that learning and assessment methods are subject to change, the programme should be flexible enough (Segers, 2004). Depending on the educational vision of an institute, different aspects of the model can be emphasized. In a more teacher-centred educational vision, communication between students will be less important. In a didactical 
model based on social constructivism and problem-based learning (Moust et al., 2002), more emphasis will be placed upon interaction among students.

Figure 2.1 Online remedial teaching model

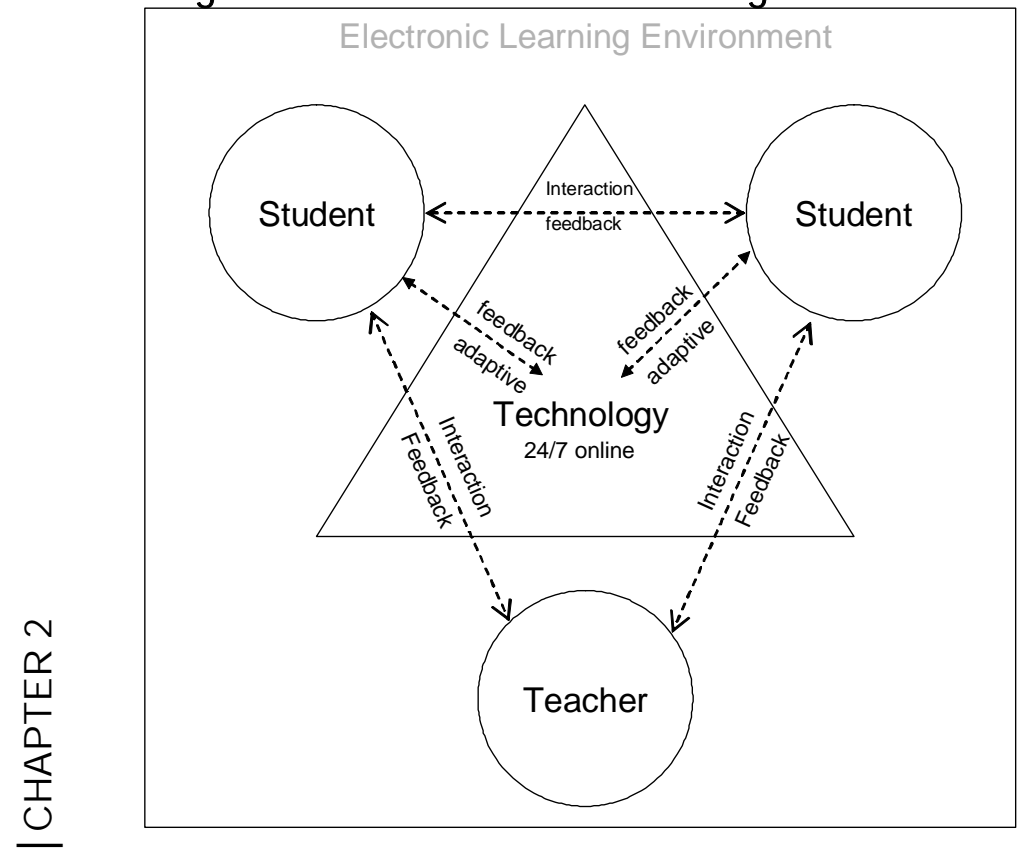

24 In Figure 2.1, our online remedial teaching model is illustrated by the aforementioned aspects and their interrelations. The model makes a distinction between technology and virtual learning environment (VLE). In other words, the model can be adjusted to different educational settings depending on the educational vision. In an individual learning programme, the interaction will mainly take place between the technology and the student (by offering learning materials, assignments and assessments) as well as between student and lecturer. In a problem-based learning setting, the interaction between students will increase with help of the technology (discussion-forums, chat, e-mail, etc.), whereas the lecturer will perform a coaching role. The way in which the student is assessed will essentially depend on the chosen didactical model (Segers, 2004). In addition, the online remedial teaching model will also determine the evaluation method. 


\section{DESIGN OF ONLINE SUMMER COURSES}

As Maastricht University has the highest percentage of international students (24\% in 2005) in the Netherlands (Ministerie van OCW, 2005), and the Faculty of Economics and Business Administration has more than $70 \%$ of enrolments from abroad, the differences in prior knowledge are enormous. The experiences how to tackle these problems provides an interesting case-study for higher educational institutes focussing on moving towards internationalisation.

Most 1st and 2nd year students in the "regular" curriculum at Maastricht University have (some) problems with mathematics and/or economics (R ienties, Dijkstra et al., 2005). Therefore, the first online summer courses were specifically developed for tackling these problems. As the majority of the target group lived abroad, the programme was offered completely online, with no physical presence required. An economics as well as the mathematics online summer course were offered twice during the summer period. This allowed for more flexibility, which enhanced the match between a student's efforts to tackle possible deficiencies for the respective topics and his/her other "summer" activities. This enabled participants to work anywhere they liked and at times that suit them best. Important to note is that participation was completely voluntary and in no way related to the official admission procedures of the university. Moreover, participation in the summer course was free of charge and the only bonus was an unofficial certificate and a graduation ceremony and drink.

\subsection{Prior knowledge tests}

A fundamental assumption is that not every student will need an online summer course. Therefore, a so-called online prior knowledge (diagnostic) test was developed before the start of the academic year. The online tests of economics and mathematics were available and accessible 24/7 via the Internet and were a combination of exercises in open-question type form and self-assessment of mastery of knowledge. Anyone who completed in the online entry test received elaborate feedback via E-mail. If the results were deemed to be below a specified threshold, students were invited to take part in the applicable summer course to remediate the apparent deficiency. If a student was willing to invest 60 to 80 hours to remediate his/her knowledge deficiency, the student was enrolled in the summer course.

Overall, the economics test was viewed 379 times and 211 prospective students from 34 different countries, ranging from Spain, Peru, Australia to Kazakhstan, completed the test. Surprisingly, 151 (71\%) prospective 
students scored below the threshold level for economics. For mathematics, 230 prospective students took the test and $83 \%$ scored below the predefined threshold-level. In total 50 students registered for economics and 55 for mathematics, mostly German students with the basic level mathematics (Abitur G rundkurs Mathematik) and no economics.

\subsection{Online summer course economics}

The online summer course economics was a virtual version of the collaborative Problem-Based Learning (e-PBL) approach used at Maastricht University (Rienties, Rehm, \& Dijkstra, 2005). The course was given over a period of six weeks in which students were assumed to work for 10-15 hours per week. There were neither obligatory meetings nor a schedule of appointments. The students themselves decided when to work on a task. They discussed six tasks that covered introductory topics of economics in general (e.g. economic way of thinking), microeconomics (e.g. demand and supply model) and macroeconomics (e.g. gross domestic product, inflation and unemployment). The 50 participants were divided in

$\sim \quad$ three groups (depending on the time of enrolment) of 14 to 18 students, in

$\stackrel{\Upsilon}{\sim} \quad$ line with analyses by Schellens \& Valcke (2006) about optimal group sizes

$\stackrel{f}{f} \quad$ for collaborative learning. All groups were guided by two tutors.

\section{Online Training}

Because participants had no experience with the seven-jump method of PBL (Moust et al., 2002) and most of them were unfamiliar with using a virtual learning environment, a lot of emphasis was placed upon training and schooling. This was a challenge since there was no face-to-face contact between tutors and participants. Therefore, three steps were taken to overcome these difficulties.

1. The six tasks were preceded by "Task 0". The purpose of this task was to demonstrate students the process of PBL in a discussion board. The coordinators of the course simulated a discussion on a related, but non-economic topic.

2. The summer course manual included a chapter that explained the content and sequence of the different steps in the seven-jump as well as a manual for the VLE.

3. During the first week, extra attention was paid to the first contributions of participants. If mistakes were made, immediate positive feedback was given (Schellens \& Valcke, 2005). 
Virtual Learning Environment

In order to participate in the discussion of the tasks, students were given access to the VLE used in Maastricht. ELEUM incorporates most of the characteristics of the online remedial teaching model. It allows students to do quizzes and give immediate feedback on their results and learning process (Rienties \& Woltjer, 2004; Tempelaar \& De Gruijter, 2004). In addition, ELEUM has some interactive communication tools like discussion boards, chat and E-mail (Ronteltap \& E urelings, 2002). As primary learning materials, an electronic version of a first year economics book from Parkin and Bade (2004) was used, which includes chapters of the book, videos, interactive materials and animated graphs.

\section{Formative and Summative Assessment}

The course used various formative as well as summative assessment forms. According to Marshall (1999), formative assessment supports the learning process of students without grading, while summative assessment gives insight in the (end) level of a student with an accompanying mark. The students had the opportunity to make three formative tests and they could themselves decide when to take the tests. These tests were used to provide the students with feedback on their level of mastery of the learned subjects. The course was concluded with a final summative exam. The students had to work on a problem similar to the ones they discussed during the course and were asked to answer it by applying the newly acquired knowledge.

\section{Interactive communication}

With regard to the problem of ensuring rapid feedback, interaction tools prove to be a very attractive mechanism. The use of a discussion-board (asynchronous communication) makes it possible for students to interact with each other, share new insights and help in case certain aspects need clarification This is in contrast to synchronous communication (e.g. chat or MSN-messenger), which requires all participants to be online at the same time. By designing a course around a-synchronous communication, a substantial degree of flexibility is created and this has been extensively researched by Computer Supported Collaborative Learning (CSCL) analyses (De Wever, Schellens, Valcke, \& Van Keer, 2006; G unawardena, Lowe, \& Anderson, 1997). This allows students to actively participate in a discussion at their preferred time without running the risk of missing vital parts. Moreover, it allows for group dynamics that are missing when a student has to follow a remedial course alone (Rienties, Rehm et al., 2005). Hence, a discussion board can be used as a formative assessment tool. 


\subsection{Online summer course mathematics}

The procedure used for the online summer course mathematics is to a large extent similar to the economics course. The workload is equivalent, namely 10-15 hours per week in a period of 4 to 6 weeks. In contrast to the economics course, the mathematics course is largely an individual course. It is based on individual learning, where nearly all interaction is between the student and the learning environment. Students worked with an online programme (ALEKS), which again assessed the prior knowledge level of students and afterwards offered a unique individual learning path. This programme is based on so-called Knowledge Space theorem (Doignon \& Falmagne, 1999). If a student goes faster (or slower) through the learning material, then ALEKS will immediately adapt the learning path. In principle, this implies that the program adapts the learning path depending on knowledge, progress and learning style of the student.

The lecturer, who is also responsible for the 1st year introduction course mathematics in the "regular" curriculum, chose a module which is similar to the complete mathematics programme in Dutch secondary education.

$\sim \quad$ Students had to solve mathematical problems and if necessary ALEKS

$\stackrel{\Upsilon}{\sim} \quad$ provided hints. Although students worked individually, they could contact

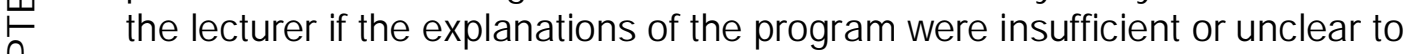
the student. The pass-fail decision was made based on the endpoint (knowledge level) a student achieved.

\section{$28 \quad 3.4 \quad$ Evaluation}

In order to analyse whether the two online summer courses were developed effectively, an evaluation was used which is based on a protocol developed by Kaper, Blok, Brouwer and Wieland (2005). This evaluation protocol takes into consideration the specific demands of flexible education with heterogeneous students. In order to be able to measure the expectations of the participants at the beginning as well as at the end of the course, online questionnaires were distributed. At the beginning, students were asked about their motives and incentives for participating in the online summer course programme. 


\section{RESULTS}

\subsection{Results of online summer course economics}

According to the entry questionnaire, students were mainly joining the course since they were not satisfied with their level of mastery in economics. The students indicated that they liked the idea of working online to remediate their knowledge and at the same time liked the opportunity to contact other students as well as the tutor. In general, the participants indicated that at the start of the course they received sufficient information about the goal and context of the course. Furthermore, the students clearly expressed their preference for teamwork instead of working individually.

During the course, the students had to collaborate on solving problems derived from PBL-tasks. When the summer course started, the students briefly introduced themselves in the "Café/Small Talk"-section with a picture and personal background information. The Café/Small Talk-section was intensively used for getting acquainted with each other, as recommended by Roblyer and Wiencke (2003). In addition, it was used for arranging practicalities such as "how to find a room?" or "where do I apply for a grant?" Thus, the online course also contributed to establishing of fidelity within the group and with the institution. One can reasonably assume that students who are more convinced about their choice of study will commit more to the institute and will put more effort in their study. By early fidelity of students towards the institute, the chance that a student gets isolated in a new environment and drops out the study in a preliminary stage is thus reduced. In the beginning, students found it difficult to understand the seven-jump. Students placed daily threads and reacted on each others' contributions. Six weeks later, an average of 370 threads per group were placed, which can be seen as a rough approximation of the intensity of usage. The highest performing student placed $27 \%$ of the messages and the lowest performing student $2 \%$ of the messages.

At the end of the course, an evaluation was conducted to see whether the course matched the expectations of the students (see Table 2.1). Students were very positive about both the functioning of the instructors as well as the online summer course as such. More specifically, students felt that the course had offered them a lot and enabled them to remediate their knowledge to such an extent that they feel ready to start in Maastricht University. Students worked over a period of six weeks 13 hours per week for the summer course on average. The group of students who did not pass only worked for six hours per week. With regard to the VLE, students found the digital materials to be of very good quality. Moreover, there is evidence that students liked the fact that they could collaborate with each other in this summer course. The students thought that it was fun to make use of

Table 2.1 Students' end evaluation of online summer course economics 


\begin{tabular}{|c|c|c|}
\hline & M & SD \\
\hline This Summer course offered me a lot & 4. 1 & 0.8 \\
\hline The contents of the Summer course were inspiring & 4. 1 & 0.6 \\
\hline The format of the Summer course was good & 4. 0 & 0.9 \\
\hline The Summer course was well organized & 4. 0 & 0.9 \\
\hline The quality of the digital material was good & 4. 3 & 0.7 \\
\hline $\begin{array}{l}\text { The digital material motivated me to keep up with the subject } \\
\text { matter }\end{array}$ & 3. 5 & 1. 0 \\
\hline $\begin{array}{l}\text { Learning with an E-book is not different from learning from a hard- } \\
\text { copy book }\end{array}$ & 2. 3 & 1. 0 \\
\hline It was fun that I could attend this Summer course via the internet & 3. 8 & 0.8 \\
\hline The goals of the Summer course were clear to me & 3. 9 & 0.8 \\
\hline It was clear to me what was expected of me this Summercourse & 3. 9 & 0.8 \\
\hline $\begin{array}{l}\text { The assignments/tasks stimulated me to collaborate with the other } \\
\text { group }\end{array}$ & 3. 6 & 0.9 \\
\hline The assignments/tasks stimulated me to study & 3. 6 & 0.8 \\
\hline $\begin{array}{l}\text { I am satisfied with what I learned in terms of knowledge, skills and } \\
\text { insight }\end{array}$ & 3. 7 & 0. 9 \\
\hline $\begin{array}{l}\text { I gained enough knowledge and skills in economics to start with my } \\
\text { study in Maastricht }\end{array}$ & 3. 7 & 0.6 \\
\hline $\begin{array}{l}\text { I think that by attending this Summer course I will get better results } \\
\text { in my future study in Maastricht }\end{array}$ & 3. 7 & 0.7 \\
\hline The group in which I participated functioned well & 3. 7 & 1. 0 \\
\hline It was fun to collaborate with others in this Summercourse & 3. 9 & 1. 0 \\
\hline $\begin{array}{l}\text { Collaborating with others facilitated my understanding of the } \\
\text { subject matter }\end{array}$ & 3. 7 & 0.7 \\
\hline The group in which I participated functioned well & 3. 8 & 0.9 \\
\hline $\begin{array}{l}\text { I think I learned more in this Summer course through collaboration } \\
\text { with others than I would have learned if I had to work }\end{array}$ & 3. 2 & 0. 9 \\
\hline I participated actively in the online group discussions & 3. 0 & 1. 2 \\
\hline $\begin{array}{l}\text { I think I was motivated to finish this Summer course because I } \\
\text { could work in my own pace }\end{array}$ & 3. 4 & 1. 1 \\
\hline It is good that I could attend this Summer course independently & 4. 1 & 0.6 \\
\hline I was given the support that I needed & 4. 1 & 0.6 \\
\hline $\begin{array}{l}\text { The Online Summer course team was enthusiastic in coaching our } \\
\text { group }\end{array}$ & 4. 1 & 0.8 \\
\hline $\begin{array}{l}\text { The Online Summer course team stimulated participation of all } \\
\text { group members in the online group discussions }\end{array}$ & 3. 5 & 0.9 \\
\hline $\begin{array}{l}\text { The Online Summer course team helped us to apply what we had } \\
\text { learned on other situations than those mentioned in the assignment }\end{array}$ & 3. 7 & 0.7 \\
\hline The entry test on the UM Website was a good test to show me what & 3. 5 & 1. 1 \\
\hline
\end{tabular}


I did know and what I did not know

The questions in the final test were clear

3. $8 \quad 0.9$

The instructions for making the final test were clear

4. 0

0. 8

The Weekly tests (intermediate tests) in this Summer course gave

3. 7

0. 7

me a good picture of what I still had to study

The programme used for the tests was easy to work with

4. 20.8

I have made ...... out of 3 Weekly (intermediate) tests

2. $5 \quad 0.9$

Give an overall grade for the quality of the Online Summer course

8. $3 \quad$ 1. 2

team ( 1 = very bad $-10=$ very good)

Give an overall grade for the functioning of the Online Summer

8. $1 \quad 1.4$

course team ( 1 = very bad $-10=$ very good)

Weekly I have spent .... hours on this course and additionally I have

spent ... hours on preparing the final test

Note: All questions on 1(= totally disagree) till 5 (= totally agree) Likert Scale except last four questions

discussion-boards and they perceived the general atmosphere in the group to be friendly. Furthermore, students had a strong feeling that the teamwork setting helped them in their process of tackling their knowledge gaps. The observation that increased interactivity in distance education is related to higher student satisfaction (and therefore higher passing rates) has already been confirmed by earlier findings by Roblyer and Wiencke (2003).

Eventually, 25 out of 50 students passed the course. In comparison to other remedial courses (Van Leijen, 2005) and taking into account that students never physically met one another and that participation was completely voluntary, a passing rate of 50 per cent can be considered to be fairly high.

\subsection{Results of online summer course mathematics}

Regarding the mathematics course, the students indicated at the beginning of the course to be highly motivated and were mainly joining the course since they were not satisfied with their level of mastery in mathematics. Students pointed out that they received sufficient information about the goal and context of the course. In contrast to the economics summer course, there were no questions regarding any form of collaboration, for the aforementioned reasons related to the usage of the individual learning tool of ALEKS. The students indicate to be motivated to complete the Summercourse as they could work at their own pace.

In the end, 29 of 55 (53\%) students successfully completed the course. Again, the students were positive about the tutor as well as the course. The course offered a lot of added value as well as a stimulating environment and had useful learning materials. Students signify that they gained enough 
Table 2.2 Students' end evaluation of online summer course mathematics

\begin{tabular}{|c|c|c|}
\hline & M & SD \\
\hline This Summer course offered me a lot & 4.5 & 0.6 \\
\hline The contents of the Summer course were inspiring & 4.2 & 0.5 \\
\hline The format of the Summer course was good & 4.3 & 0.7 \\
\hline The Summer course was well organized & 4.4 & 0.7 \\
\hline The quality of the material in ALEKS is good & 4.3 & 0.7 \\
\hline $\begin{array}{l}\text { The material in ALEKS motivated me to keep up with the subject } \\
\text { matter }\end{array}$ & 3.9 & 0.7 \\
\hline $\begin{array}{l}\text { Learning in an e-learning environment as ALEKS is not different } \\
\text { from learning from a hard-copy book }\end{array}$ & 2.4 & 0.9 \\
\hline It was fun that I could attend this Summer course via the internet & 4.2 & 0.8 \\
\hline $\begin{array}{l}\text { The time allocated was sufficient to study the amount of subject } \\
\text { matter }\end{array}$ & 3.2 & 0.8 \\
\hline The goals of the Summer course were clear to me & 4.1 & 0.6 \\
\hline $\begin{array}{l}\text { The contents of the Summer course fitted well with my pre-existing } \\
\text { knowledge }\end{array}$ & 3.6 & 0.9 \\
\hline The format of the Summer course was good & 4.2 & 0.5 \\
\hline The way one has to work in ALEKS is straightforward & 4.0 & 0.9 \\
\hline The assignments/tasks stimulated me to study & 3.9 & 0.8 \\
\hline $\begin{array}{l}\text { I gained enough knowledge and skills in mathematics to start with } \\
\text { my study in Maastricht }\end{array}$ & 3.5 & 0.8 \\
\hline $\begin{array}{l}\text { I think that by attending this Summer course I will get better results } \\
\text { in my future study in Maastricht }\end{array}$ & 3.9 & 0.8 \\
\hline $\begin{array}{l}\text { It is easy to understand how to operate in the ALEKS learning } \\
\text { environment }\end{array}$ & 4.5 & 0.6 \\
\hline It was fun to work with ALEKS independently & 4.2 & 0.7 \\
\hline It was good that I could work on the subject matter at my own pace & 4.5 & 0.6 \\
\hline $\begin{array}{l}\text { I think that I have learned more by individually attending this } \\
\text { course than I would have learned if I had to collaborate }\end{array}$ & 3.5 & 1.0 \\
\hline I was given the support that I needed & 4.0 & 0.8 \\
\hline $\begin{array}{l}\text { The explanation in ALEKS in case one is unable to solve a question } \\
\text { is generally sufficient }\end{array}$ & 3.8 & 0.9 \\
\hline $\begin{array}{l}\text { Next to the explanations in ALEKS I have used hard-copy books on } \\
\text { mathematics }\end{array}$ & 1.9 & 1.1 \\
\hline Questions via e-mail were answered well by the teacher & 3.8 & 0.8 \\
\hline $\begin{array}{l}\text { The entry test on the UM Website was a good test to show me what } \\
\text { I did know and what I did not know }\end{array}$ & 3.8 & 1.0 \\
\hline The questions in the ALEKS-tests were clear & 3.9 & 0.8 \\
\hline It was easy to see how the ALEKS-tests had to be done & 4.1 & 0.8 \\
\hline The intermediate tests in ALEKS were instructive & 3.6 & 0.8 \\
\hline
\end{tabular}


The intermediate tests in ALEKS gave me a good picture of what I

still had to study

I worked regularly on the assignments/tasks in this Summer course

It was easy to motivate myself to finish this Summercourse

Give an overall grade for the quality of this Summer course( $1=$

very bad - $10=$ very good)

Give an overall grade for the quality of support you were given by

ALEKS in this Summer course ( 1 = very bad $-10=$ very good)

In total, I spent .... hours on this Summercourse

Note: All questions on 1 (= totally disagree) till 5 (= totally agree) Likert Scale except last four questions

knowledge and skills to make a successful start of their study. Students worked on average 53 hours during the course. In contrast to economics, they preferred to work individually rather than working together. In table 2.2, the complete evaluation results are given.

Remarkably, students who participated in both courses judged both didactical scenarios to be adequate. The question which arises is: are students indifferent about the didactical scenario, or do they judge that individual learning best suits the mathematics summer course, and collaborative learning best suits the economics summer course, and that the designers of both types of summer courses made appropriate choices for the didactical scenarios?

\subsection{Comparing the didactical scenarios}

The two summer courses are based on completely different didactical scenarios. The mathematics course is based on purely individual learning, where nearly all interaction is between the student and the learning environment. Neither interaction with peer students takes place nor extensive interaction with the tutor. In contrast, the economics course is based on collaborative learning supported by a VLE. One of the aims of having both summer courses founded in such different learning paradigms was to collect empirical evidence on the appropriateness of both scenarios when applied for online, distance summer courses. As indicated above, both summer courses appeared to be successful in terms of better preparing students with deficient prior knowledge for their regular study. Comparing drop-out ratios, no strong differences have been found. A similar remark refers to students' satisfaction based on the evaluation questionnaire: both courses, and thus both didactical scenarios, achieve positive evaluations on all criteria.

To answer this last question, one item in the evaluation questionnaire of both summer courses asked the students to judge the appropriateness of the didactical scenario, with the other didactical scenario as benchmark. In 
the mathematics course, students were asked to express themselves on the statement 'I think that I have learned more by individually attending this course than I would have learned if I had to collaborate'. In contrast to this, the statement has been formulated in the reverse way for the participants of the economics course. This statement received an average score of 3.5 for the mathematics summer course, and a 3.2 score for the economics summer course. Thus, although scores are less pronounced than in most other evaluation items, there is a tendency that individual learning is regarded more suitable for the mathematics summer course, and collaborative learning most suitable for the economics summer course. Students' opinion on the appropriateness of the didactical scenario is dependent upon success in the summer course. In fact, it is the only evaluative statement where a "passing student" provides an answer that is significantly different from the answer provided by a "failing student". This might indicate that some students fail the summer course because they regard the didactical scenario applied in the summer course as suboptimal.

\section{DISCUSSION}

In this chapter, the question how prior knowledge tests and online remedial summer courses can contribute to mitigating the problems of heterogeneous enrolment of students has been dealt with. First of all, an online remedial teaching model was developed. The five success factors that an online remedial course developer should take into account are 24/7 access and availability via Internet, adaptiveness, interactivity, rapid feedback, and flexible learning methods and assessment.

Afterwards, the online remedial teaching model was implemented in practice at for two summer courses of the Maastricht University. Before students were allowed to join one/both of the courses, they had to make an online prior knowledge test. More than 200 prospective students out of more than 30 countries made use of this possibility. A large amount $(\geq 75 \%)$ of the prospective students scored below the threshold on the prior knowledge test mathematics and/or economics. This suggests some proof for our assumption that, due to internationalisation, problems in higher education with regard to prior knowledge in mathematics and economics are wide-spread. Eventually, approximately $2 * 50$ students took part in one or both of the online summer courses. As most (prospective) students of Maastricht University live abroad before joining the academic programme, the courses were offered $100 \%$ online.

Although both courses implemented a different didactical scenario, both matched with the online remedial teaching model. The didactical model fitted the content of the course of economics and mathematics, respectively 
ePBL and working individually with ALEKS. Positively, most of the participants spent a substantial amount of time on the course and the passing rates are at least similar to other experiments of online virtual learning. The student evaluations of both courses were very positive and students indicated they felt ready to start their study at Maastricht University. More specific, there seems to be some evidence that individual learning is regarded more suitable for the mathematics summer course, and collaborative learning more suitable for the economics summer course. The implementation of both summer courses was mainly focused on didactical and organizational aspects, since the technical infrastructure was already in place. Both courses are implemented using existing ICTinfrastructures, comparable to other higher education institutes. As long as sufficient expertise and resources are invested, the problems accompanying the increasing internationalization of students can be tackled.

Further research is necessary to prove whether online summer courses have a temporary or structural effect on the (prior) knowledge level of students. In addition, it remains to be investigated whether the participants, in comparison to those who did not take part at the summer course, perform better in the respective courses in the curriculum. Furthermore, a so-called "sample bias" might have occurred. Therefore, the participation of students will be followed during their "regular" curriculum by means of a longitudinal study. Finally, more research is needed on the motivation of participants. In future summer courses, the subgroups of participants of the summer courses will be enlarged and the didactical scenarios will be implemented at other institutes. To enlarge the statistical power of the research, more specified and detailed information about the subgroups will have to be gathered.

\section{References}

Abdullah, S. (2003). Student Modelling by Adaptive Testing - A Knowledgebased Approach. Unpublished Dissertation. University of Kent. .

Bryant, S., Khale, J., \& Schafer, B. (2005). Distance Education: A Review of the Contemporary Literature. Issues in Accounting Education, 20(3), 255272.

De Vries, R., \& Van der Velden, R. (2005). Brug of Kloof? De ervaringen van HAVO- en VWO-schoolverlaters over de aansluiting tussen VO en HO

vóór en ná de invoering. tweede fase VO, . Maastricht: Researchcentrum voor Onderwijs en Arbeidsmarkt, Faculteit der Economische Wetenschappen en Bedrijfskunde, Universiteit Maastricht.

De Wever, B., Schellens, T., Valcke, M., \& Van Keer, H. (2006). Content analysis schemes to analyze transcripts of online asynchronous discussion groups: A review. Computers \& Education, 46(1), 6-28.

Dittrich, K., \& Frederiks, M. (2005). Accreditatie in Nederland en Vlaanderen: een eerste balans. Tijdschrift voor Hoger Onderwijs, 1. 
Doignon, J., \& Falmagne, J. (1999). Knowledge Spaces. Berlin: Springer.

Gunawardena, C. N., Lowe, C. A., \& Anderson, T. (1997). Analysis of a global online debate and the development of an interaction analysis model for examining social construction of knowledge in computer conferencing. Journal of Educational Computing Research 17(4), 397-431.

Kaper, W., Blok, G., Brouwer, N., \& Wieland, A. (2005). Evaluatieprotocol voor flexibel onderwijs bij heterogene instroom. Universiteit van Amsterdam, Universiteit Maastricht, Erasmus Universiteit Rotterdam.

Keegan, D. (2002). Definition of distance education. Distance Education: Teaching and Learning in Higher Education. Boston, MA. : Pearson Custom Publishing.

Marshall, G. (1999). Exploring Assessment. Education and Information Technologies, 4(3), 313-329.

Ministerie van OCW. (2005). Kennis in Kaart Den Haag: Ministerie van Onderwijs, Cultuur en Wetenschap.

Moust, J., Bouhuijs, P., \& Schmidt, H. G. (2002). Problem-Based Learning: A student guide. Groningen: Wolters-Noordhoff.

Onderwijsraad. (2005). Helft Nederland Hoogopgeleid door ander Hoger Onderwijs. Retrieved 1 September, 2009, from http://www. onderwiisraad. $\mathrm{nl} /$ actueel/persberichten/helft-nederlandhoogopgeteid-door-ander-hoger-onderwijs

Parkin, M., \& Bade, R. (2004). Foundations of Economics (2 ed.). Boston: Pearson.

Prins, J. (1997). Studieuitval in het wetenschappelijk onderwijs. University of Nijmegen, Nijmegen.

Rienties, B., Dijkstra, J., Rehm, M., Tempelaar, D. T., \& Blok, G. (2005). Online Bijspijkeronderwijs in de Praktijk. Tijdschrift voor Hoger Onderwijs, 4, 239-253.

Rienties, B., Rehm, M., \& Dijkstra, J. (2005). Remedial online teaching in theory and practice; online summer course: Balance between summer and course Paper presented at the Balance, fidelity, mobility: Maintaining the momentum? Proceedings of the 22nd Annual Conference of the Australasian Society of Computers in Learning in Tertiary Education Brisbane.

Rienties, B., \& Woltjer, G. (2004). Regular On-line Assessment, Motivation and Learning. Meteor Research Memorandum(RM04030).

Roblyer, M., \& Wiencke, W. (2003). Design and use of a rubric to assess and encourage interactive qualities in distance courses. American Journal of Distance Education, 17(2), 77-98.

Ronteltap, F., \& Eurelings, A. (2002). Activity and Interaction of Students in an Electronic Learning Environment for Problem-Based Learning. Distance Education, 23(1), 11-22.

Schellens, T., \& Valcke, M. (2005). Collaborative learning in asynchronous discussion groups: What about the impact on cognitive processing? Computers in Human Behavior, 21(6), 957-975. 
Schellens, T., \& Valcke, M. (2006). Fostering knowledge construction in university students through asynchronous discussion groups. Computers \& Education, 46(4), 349-370.

Segers, M. (2004). Assessment en leren als een twee-eenheid: onderzoek naar de impact van assessment op leren. Tijdschrift voor Hoger Onderwijs, 4, 188-219.

Tempelaar, D. T., \& De Gruijter, D. (2004). Computertoetsing in de Emergeinstellingen. Leiden: E-merge.

Tweede Fase Adviespunt. (2005). Zeven jaar Tweede Fase, een balans. Den Haag: Tweede Fase Adviespunt.

Van Leijen, M., (eds) (2005). Quick scan onderzoek naar de initiatieven elders Amsterdam: Universiteit van Amsterdam, Universiteit Maastricht, Erasmus Universiteit Rotterdam.

Vrasidas, C., \& Mclsaac, S. M. (1999). Factors influencing interaction in an online course. The American Journal of Distance Education, 13(3), 2236.

Vrasidas, C., \& Zembylas, M. (2003). The Nature of Technology-mediated Interaction in Globalised Distance Education. International Journal of Training and Development, 7(4), 271-286.

Vygotsky, L. S. (1978). Mind in society. Cambridge, MA: Harvard University Press.

${ }^{\mathrm{i}}$ The results of this paper are part of the project "Web-spijkeren" (http://www.web-spijkeren.nl/), which is a collaboration of the University of Amsterdam, the Erasmus University Rotterdam and the Maastricht University. The word "Web-spijkeren" is a Dutch combination of two words, namely Web (online) and "bijspijkeren" (remedial teaching). This paper was financed in part by National foundation of ICT in Higher Education SURF, ICT en Onderwijs, Tender 2004 and Maastricht University. 